\title{
JURNALISME REPORTASE: SEBUAH PRODUK KOMERSIALISASI DALAM INDUSTRI TELEVISI
}

\author{
Oleh: Gita Aprinta E.B \\ (gita@ftik.usm.ac.id)
}

\author{
(Staf Pengajar Program Studi Ilmu Komunikasi Universitas Semarang)
}

\begin{abstract}
The freedom of press has given space to the growth of television industries in Indonesia. As we all know, since 2010 there are at least nine private television that established. This case has been impact to the public information fulfilness. Unfortunately as part of the capitalism industry, television should able to provide information that give two function, these is entertainment and journalism. Therefore, information is so often considered as commodity relate with the market mechanism that create television commercialization.

This article aim to observe the bias of information that affected by journalism technique in the investigation program called. "Reportase Investigasi" through the approach Marxis capitalism where in the world of capitalism production is always relate with power and capital ownership.
\end{abstract}

Kata Kunci: Journalism, Television, Commersialitation, Report, Investigati

\section{Pendahuluan}

Kebebasan pers di era reformasi memberikan ruang bagi tumbuhnya media massa di Indonesia. Salah satunya adalah kemunculan beragam TV Swasta, dimulai dengan RCTI (Rajawali Citra Televisi Indonesia) pada tahun 1989. kemudian diikuti secara berturut - turut oleh SCTV, TPI, Indosiar, dan Antv. Di tahun 2010 tercatat sebanyak 9 TV Swasta Nasional dan lebih dari 5 TV Swasta Regional yang beroperasi di Indonesia. Dengan menjamurnya industri TV Swasta tersebut, menuntut masing - masing stasiun TV untuk dapat mengembangkan program acaranya sebaik mungkin agar tidak tergerus dengan persaingan yang ada. Tidak

terkecuali dengan program berita yang disajikan. Berita merupakan sebuah pusat informasi bagi masyarakat, tempat dimana publik dapat mengkonsumsi kebutuhan akan arus informasi yang tersaji melalui televisi.

Dengan keberadaan televisi yang tidak hanya sekedar menjadi penyampai informasi yang aktual saja tetapi juga sebagai bagian dari industri kapitalis, tentunya berita yang disajikan tidak boleh menjadi berita yang biasa saja. Dibutuhkan sebuah kreatifitas tersendiri untuk membuat sebuah berita tidak terlihat membosankan karena hal tersebut berkaitan dengan pilihan masyarakat. Sebuah televisi yang berhasil mengemas program berita

THE MESSENGER, Volume IV, Nomor 1, Edisi Januari 2012 
dengan menarik tentu saja akan menjadi rujukan bagi pemirsa dalam mengakses informasi yang menjadi kebutuhan mereka. Sehingga tidak mengherankan bila terdapat beragam konsep dan teknik yang digunakan oleh masing-masing televisi dalam membuat berita mengingat televisi sudah menjadi bagian industri populer yang mempunyai efek tersendiri dalam mempengaruhi perilaku masyarakat di ranah publik.

Adalah sebuah tantangan bagi pekerja media, khususnya jurnalis untuk dapat membuat sebuah laporan yang sarat dengan kreatifitas guna mendapat aprsesiasi tinggi dari para penonton. Kreatifitas tersebut meliputi fakta sosial yang terjadi di masyarakat, ide peliputan, peliputan, pembuatan naskah berita hingga sampai pada penyuntingan gambar. Kegiatan proses perjalanan berita tersebut terangkum dalam apa yang dinamakan sebagai jurnalisme.

Jika dilihat dari sejarahnya, jurnalisme televisi sendiri berkembang sejak tahun 40-an, mulai dari semacam jurnalisme radio yang ditampilkan dibawah lampu terang dan kamera, sampai teknologi satelit dan media interaktif dalam pemberitaan. Sementara di Indonesia jurnalisme yang berkenaan dengan televisi swasta baru menggeliat di awal tahun 90-an. Pada dasarnya jurnalisme adalah kaidah kerja dalam memungut fakta sosial untuk dijadikan informasi, kemudian disampaikan melalui media massa. Kaidah jurnalisme mengandung standard dalam memilih fakta sosial dan mewujudkan informasi ${ }^{1}$. Atau dapat dikatakan pula bahwa secara teknis, jurnalisme televisi menjadikan fakta sosial sebagai tontonan.

Sebagai sebuah televisi komersil, televisi swasta mengemban dua fungsi sekaligus yaitu fungsi hiburan dan jurnalisme. Informasi dianggap sebagai barang dagangan atau komoditi. Berita yang tersaji di masyarakat cenderung sesuatu yang sensasional dan spektakuler,dengan harga apapun, yang terkadang sampai mengorbankan profesionalisme $^{2}$. Hal ini berkenaan dengan industri televisi itu sendiri yang memiliki sifat ekonomi dimana televisi swasta menjadi faktor pendukung penting dalam mekanisme pasar.

Oleh karena itu, setiap tayangan program televisi tidak termasuk juga berita memiliki prosentasi pemirsa yang disebut rating. Semakin banyak pemirsa yang menyukai sebuah program maka semakin tinggi angka rating program tersebut demikian juga sebaliknya. Apabila rating sebuah program rendah maka akan sulit pula meraup iklan yang merupakan nafas bagi industri televisi. Karena tayangan berita harus bersaing dengan program lain untuk mendapatkan rating yang tinggi, maka dapat dipastikan semua awak yang terlibat dalam sebuah stasiun pemberitaan akan berlomba menyajikan tayangan yang terbaik. Salah satu pilar

\footnotetext{
${ }^{1}$ Siregar, Ashadi dalam artikel Trend Jurnalisme Televisi

${ }^{2}$ Haryatmoko, Etika Komunikasi:

Manipulasi Media, Kekerasan dan

Pornografi; 2007 p. 21
} 
yang menentukan kualitas tayangan berita TV tersebut adalah bagaimana sebuah tayangan itu dikemas melalui sebuah proses produksi ${ }^{3}$.

Berkaitan dengan masalah rating tersebut maka munculah program siaran berita dalam berbagai model. Salah satunya adalah investigasi. Model berita investigasi ini merupakan salah satu bentuk informasi yang dikemas lebih dalam untuk mendapatkan fakta - fakta dari sebuah peristiwa yang aktual. Beberapa stasiun TV Swasta pun menerapkan model investigasi ini tak terkecuali Trans TV. Trans TV bahkan membuat sebuah program investigasi sendiri berjudul 'Reportase

Investigasi'. Program yang tayang setiap hari Sabtu dari pukul 17.00 17.30 merupakan program buletin dari Divisi News Trans $\mathrm{TV}^{4}$. Reportase Investigasi mengungkap suatu kasus penyimpangan, dari pelakunya langsung. Topik yang dipilih adalah yang menjadi kepentingan masyarakat. Misalnya, tentang bakso yang mengandung boraks, kosmetika yang mengandung zat berbahaya bagi kesehatan, dan sebagainya.

Dengan menggunakan perekam tersembunyi, para jurnalis investigasi seolah - olah membawa permirsa untuk turut serta dalam penyelidikan melalui gambar - gambar visual yang

\footnotetext{
3

http://www.lintasberita.com/Entertainment/S ains/Proses_Produksi_Berita_TV

4

http: //www.transtvnews.co.id/index.php/Sino psis/reportase-investigasi.html - tgl akses 9 Mei 2010, pukul $4.14 \mathrm{pm}$.
}

dihasilkan. Hal tersebut tentu saja akan menggiring rasa penasaran pemirsa untuk terus menunggu - nunggu gambar ekslusif apa selanjutnya. Di tambah dengan wawancara terhadap pelaku dengan suara yang disamarkan yang membuat liputan investigasi tersebut mengungkapkan sebuah fakta sebenarnya yang tidak pernah diketahui oleh masyarakat sebelumnya.

Sejatinya, sebuah liputan investigasi bisa saja menuntun kita pada sebuah kerancuan informasi karena program investigasi cenderung menampilkan sisi dramatis dari sebuah fakta sosial sehingga dapat membawa kebingungan informasi bagi para pemirsa. Sisi dramatis yang ditampilkan melalui gambar-gambar dan narasi justru akan menghilangkan esensi dasar jurnalisme investigasi itu sendiri. Investigasi yang dilakukan biasanya malah melenceng jauh dari definisi investigasi itu sendiri. Yang terjadi adalah terjadi pembenaran bahwa gambaran dalam pemberitaan investigasi itu merupakan kenyataan.

Deadline menjadi alasan bagi para jurnalis untuk melakukan liputan yang tidak didasarkan pada fakta dan informasi yang cukup. Kadang kadang hanya berupa isu populer dalam masyarakat yang dikemas dengan sedikit melodrama sehingga apa yang ditampilkan adalah isu yang dijadikan fakta. Selain itu kepentingan industri kapitalis juga mempengaruhi liputan investigasi yang dilakukan. Dalam rangka memaksimalkan keuntungan dan mengakumulasikan modal maka sebuah industri televisi akan melakukan intervensi terhadap program acaranya. 
Liputan investigasi tidak sepenuhnya merupakan laporan independen dari para jurnalis, tetapi ada campur tangan dari pihak-pihak lain yaitu stasiun televisi itu sendiri sehingga hasil dari liputan investigasi tersebut adalah hasil yang telah diskenariokan karena sebuah kepentingan.

Demi kepentingan tersebut sebuah program promosi sekalipun bisa dikemas sedemikian rupa menjadi berita, seperti pada tayangan reportase investigasi edisi 1 Mei 2010 tentang pembuatan terasi palsu. Beberapa kali tampak dengan sengaja iklan salah satu perusahaan pembuat terasi di Indonesia muncul dalam beberapa kali visualisasi gambar, walaupun pada saat itu reporter tengah mewawancari pelaku pembuat terasi palsu. Liputan investigasi yang memaparkan pembuatan terasi palsu yang dicampur bahan-bahan berbahaya oleh salah satu pembuat terasi skala menengah ke bawah atau lebih kerennya industri rumah tangga ${ }^{5}$ akan memberikan wacana tersendiri bagi masyarakat, bahwa produsen terasi yang tampak pada iklan tersebut adalah pembuat terasi asli yang aman untuk dikonsumsi sementara semua pembuat terasi rumahan harus diwaspadai dan dicurigai. Gambaran tersebut memberikan kedangkalan informasi bagi masyarakat dan tanpa sadar akan memberikan efek yang cukup besar terhadap industri kecil terutama para pekerjanya.

5

http://politikana.com/baca/2010/05/03/invest igasi-trans-tv-sebuah-produk-jurnalistik-atauiklan-komersial.html, akses 17 Mei 2010 pukul $8.41 \mathrm{pm}$.
Selaiknya dalam kegiatan jurnalisme, obyektifitas dan faktualitas adalah dua hal yang perlu dikedepankan untuk mendapatkan kebenaran atas sebuah informasi. Tetapi pada kenyataannya tidak berlaku dalam logika kapitalisme industri televisi. Rating dan sponsor merupakan satu kesatuan dari program berita yang dibuat dalam rangka meraih keuntungan sebanyak - banyaknya. Jurnalis hanya merupakan bagian dari konspirasi kapitalisme. Dengan memanfaatkan sebuah proses investigasi yang dibuat secara khusus dan ekslusif dalam waktu relatif singkat, menjadikan liputan investigasi tersebut layak untuk dipertanyakan kebenaran dan keakuratan data datanya. Karena pada dasarnya menurut Andre Harsono dalam praktek jurnalisme investigatif cara pencarian data harus memakan waktu cukup lama bahkan sampai bertahun - tahun hal ini dikarenakan pencarian sumber yang cukup lama. Karya investigasi tidak bisa dibuat hanya dengan mengandalkan laporan keterangan polisi atau keterangan pers orang atau lembaga swadaya masyarakat tertentu.

Sementara berkenaan dengan profesi jurnalis itu sendiri dalam kaidah jurnalisme, seorang jurnalis harus dapat memenuhi kaidah secara etik dan epistemologi. Kaidah etik berhubungan dengan kewajiban moral yang harus dijalankan bersifat normatif dan universal menuntut kesadaran etis pada tataran eksistensi untuk dapat dihayati oleh pelaku yang bertumpu pada hati nurani atau disebut kode perilaku dan kaidah epistemologi berhubungan 
dengan metodologi dan prosedur teknis jurnalisme ${ }^{6}$.

Dengan demikian kode perilaku metode kerja dijabarkan secara teknis untuk memenuhi kaidah epistemologi dan etika untuk memenuhi hakekat jurnalisme yaitu kebenaran. Idealnya adalah seorang jurnalis hendaknya dapat memilih fakta dan menyajikan kebenaran dalam setiap informasi yang disajikan. Namun mengingat bahwa di dalam jurnalistik terdapat beberapa ranah yang ditempati oleh seorang jurnalis, salah satunya adalah posisinya dalam media tempatnya bekerja, maka isi berita akan selalu terkait dengan berbagai kepentingan kapitalis.

\section{MODE PRODUKSI KAPITALIS}

Dalam wacana ekonomi Marxis ${ }^{7}$, mode produksi kapitalis mengacu pada basis sosial ekonomi masyarakat kapitalis yang tumbuh pesat di Eropa Barat pada akhir abad 18, dan kemudian diperluas ke berbagai belahan dunia. Karl Marx menyakini bahwa basis material ekonomi menentukan suprastruktur, dan sebaliknya bahwa suprastruktur hanyalah cerminan dari basis material ekonomi. Basis material ekonomi adalah tata cara produksi yang terdiri dari kekuatan produksi dan hubungan kerja dalam masyarakat kapitalis merupakan hubungan kerja antara pemilik modal dan pekerja. Oleh

\footnotetext{
${ }^{6}$ Siregar, Ashadi dalam artikel Etika Jurnalisme Televisi

${ }^{7}$ Marx, Karl and Frederick Engels. The German Ideology Part One, with Selections from Parts Two and Three, together with Marx's "Introduction to a Critique of Political Economy
}

karena itu hubungan kerja antara penguasa dan pekerja penuh kontradiksi dimana terus menerus akan terjadi pertentangan kepentingan yang mendasar dan tak terelakkan. Penguasa mempunyai kepentingan untuk mengakumulasikan kapital yang diinvestasikannya, sedangkan pekerja menjual tenaga, pikiran dan waktu luangnya untuk mendapatkan kesejahteraan ekonomi. Secara empiris, kepentingan pengusaha dan kepentingan pekerja akan selalu berbenturan karena logika akumulasi modal pasti menghisap nilai lebih yang seharusnya menjadi hak pekerja.

Konflik dalam hubungan kerja tersebut datang seiring dengan pengembangan aspek-aspek yang menentukan kekuatan produktif, yang telah dicapai pada level tertentu. Hal tersebut membawa pada sebuah perubahan yang tidak dapat terelakkan lagi pada proses produksi. Perubahan itu berkaitan erat dengan hubungan produksi, yang berarti bahwa terjadi peralihan dari basis ekonomi lama menjadi basis ekonomi baru dan menuntun pada sebuah perubahan cepat pada segenap aspek masyarakat. Perubahan dalam mode produksi tidak berasal dari manusia melainkan dari korespondensi antara karakter hubungan produksi dan tingkatan dalam pengembangan kekuasaan produktif.

Dasar dari hubungan produksi adalah kepemilikan atas alat-alat produksi. Ketika alat - alat produksi menjadi properti umum maka setiap orang mempunyai kemampuan yang sama untuk melatih kebebasan mereka dalam 
hubungan dengan kekuasaan produktif melalui struktur sosial dan politik dalam masyarakat. Sejauh mereka menikmati hak - hak yang sama sehingga mereka dapat melaksanakan hak-hak dalam pembangunan masyarakat secara nyata tanpa terhalang oleh hambatan kepemilikan pribadi.

Posisi jurnalis dimanfaatkan oleh industri televisi untuk mengakumulasikan kapital modal yang dinvestasikan, sehingga dapat dikatakan bahwa jurnalis mempunyai peran penting sebagai penentu dari jalannya sebuah ekonomi dari industri pertelevisian tersebut. Namun perlu juga dipertimbangkan, bahwa jurnalis juga mempunyai sebuah tanggung jawab moral terhadap hasil liputannya.

Dalam mode produksi kapitalis, semua atau sebagian besar input dan output produksi dipasok secara komersil melalui pasar. Hal ini tentunya memiliki konsekuensi penting pengaturan seluruh proses produksi mengubah wajah sesuai dengan rasionalitas ekonomi kapitalisme, yang dinyatakan dalam hubungan biaya produksi. Artinya bahwa seluruh proses produksi diatur dan dibentuk kembali agar sesuai denganb logika komersil. Dengan kata lain bahwa akumulasi modal menjadi motif yang mendasari produksi.

Pada konteks ini Marx mengacu pada transisi dari 'formal subsumption' ke 'real subsumption' dari produksi dibawah kekuasaan modal, yang dinamakan sebagai 'cara khusus model produksi kapitalis' kerjasama antara teknologi maupun serikat pekerja telah diperbaharui dan dibentuk ulang dalam cara cara komersial dan cara produksi lama telah sepenuhnya digantikan oleh industrialisme modern ${ }^{8}$.

Secara umum, kapitalisme sebagai sebuah sistem ekonomi dan juga sebagai bagian dari mode produksi dapat dirangkum dengan beberapa hal di bawah ini ${ }^{9}$ :

a. Capital Accumulation, produksi untuk keuntungan dan kebutuhan produser untuk mengakumulasi modal dalam rangka produksi.

b. Commodity Production, produksi dilakukan untuk kepentingan pertukaran pasar, yaitu lebih digunakan sebagai maksimalisasi nilai tukar dibanding nilai guna.

c. Private Ownership atas alat - alat produksi, kepemilikan mode produksi oleh kelas pemilik modal, baik itu individu, kolektif atau negara yang melayani kepentingan kelas kapitalisme.

d. Primacy of Wage Labor, ketergantungan terhadap upah kerja oleh sebagian besar mayoritas, memaksa mereka bekerja dan dieksplotasi oleh pemilik modal.

\section{KOMERSIALISASI TELEVISI}

Sebagai sebuah industri kapitalis, televisi merupakan sebuah ladang bisnis yang menjadikan televisi tidak lagi memegang prinsip - prinsip jurnalisme secara tepat. Prinsip jurnalisme yang berlaku adalah sesuatu yang dapat menghasilkan materi berlimpah, padahal pada dasarnya prinsip jurnalisme tidak bisa dikaitkan dengan uang. Televisi atau pemilik media

\footnotetext{
${ }^{8}$ Marx, Karl and Engels, Frederich ibid

${ }^{9}$ www.marxist.org, tanggal akses 18 Mei 2010, $8.27 \mathrm{pm}$
} 
kerapkali memaksa wartawan untuk menyajikan berita yang dapat menghasilkan keuntungan melalui pemasangan iklan.

Oleh karena tuntutan tersebut, para jurnalis tidak hanya sekedar menyampaikan informasi terhadap masyarakat tetapi juga bagaimana membuat informasi tersebut terlihat penting dan menarik sehingga terkadang esensi informasi dihilangkan dan lebih mementingkan estetika yang memukau banyak orang. Cara kerja jurnalis yang berimbang dalam pemberitaan cenderung tergantikan dengan faktor rating dan komersialisasi untuk mendapatkan pemasukan berupa pemasangan iklan dalam setiap acara yang diproduksi oleh stasiun televisi.

Salah satunya adalah penempatan iklan dalam reportase investigasi episode pembuatan terasi palsu. Nampak jelas bahwa, reportase investigasi tersebut digiring untuk membuat justifikasi mengenai keberadaan produsen terasi melalui iklan tersebut. Karena sebagai kapitalis juga, pemasang iklan berharap mendapatkan pasar untuk memasarkan komoditi dan memperoleh pembeli potensial yang itu berarti keuntungan atau profit. Sehingga dapat dikatakan bahwa dalam basis material struktur pemilik media telah melakukan eksploitasi baik terhadap pemasang iklan dan jurnalis untuk mengakumulasi modalnya.

Pada akhirnya kepentingan bisnis cenderung menggantikan kepentingan pemberitaan inilah yang membuat baik jurnalis maupun industri televisi tersebut lupa akan tanggung jawab utama jurnalisme yaitu menyampaikan informasi yang sebenar-benarnya kepada masyarakat. Fenomena komersialisasi tersebut dirasakan secara signifikan semakin menyatu dengan konsep liberalisasi dan ekonomi kapitalis global ${ }^{10}$.

Kebebasan pers Indonesia juga mendorong bergesernya prinsip jurnalisme dan karakter isi media karena sebagaimana yang disampaikan oleh Croteau (2001) bahwa media massa sekarang menempatkan masyarakat atau audiens sebagai consumer bukan warga negara. Tujuan utama media adalah menghasilkan keuntungan bagi pemilik dan pemegang saham kemudian mendorong audiens untuk menikmati dirinya melalui iklaniklan dalam televisi dan pada akhirnya membeli produk-produk yang diiklankan tersebut. Karena itu apa yang dianggap menarik bagi publik oleh media adalah apapun yang populer di masyarakat. Dengan demikian tujuan ideal media adalah untuk mempromosikan kegiatan warganegara melalui informasi, pendidikan dan integrasi sosial tenggelam dalam gelombang komersialisasi dan liberalisasi ${ }^{11}$.

\footnotetext{
ANALISIS

${ }^{10}$ Subiakto, Henry. Artikel Konsentrasi Media Massa dan Melemahnya Demokrasi -

www.jurnal.unair.ac.id, tanggal akses $21 \mathrm{Mei}$ 2010 jam 21.58 pm

${ }^{11}$ Croteau, David \& Hoynes, William , The Bussiness of The Media, Corporate Media and the Public Interest.
} 
Televisi sebagai sebuah industri kapitalis yang sarat dengan berbagai kepentingan maka bisa dipastikan bahwa proses dalam produksi berita atau pemberitaan ditentukan oleh oleh struktur ekonomi media. Ideologi jurnalis menjadi tidak penting lagi. Jurnalis sebagai human agencies seharusnya mempunyai otonomi, kreatifitas dan idealisme dalam melakoni tugas jurnalisme namun bagaimanapun media dalam hal ini stasiun televisi sebagai sebuah struktur sosial merupakan institusi bisnis yang berorientasi pada akumulasi modal dan beroperasi dalam struktur yang memiliki kaidah dan logikanya sendiri sehingga jurnalis tidak dapat dengan serta merta menggunakan media untuk mengekspresikan idealisme dan kreatifitas mereka tanpa adanya struktur yang membatasi ruang gerak para agen sosial tersebut.

Sebuah fitur mendefinisikan kapitalisme sebagai ketergantungan pada upah tenaga kerja untuk segmen besar penduduk; khusus, kelas pekerja yang tidak memiliki modal harus hidup dengan menjual tenaga kerja mereka untuk mendapatkan imbalan upah (Marx dan Engels, 2001). Jurnalis adalah bagian dari kelas pekerja yang membutuhkan satu struktur yakni industri televisi dalam rangka pemenuhan kebutuhan sebagaimana merupakan pondasi dari mode produksi yaitu sebagai sebuah metode kebutuhan hidup, di mana produksi dimulai dengan pengembangan aspek-aspek yang menentukan kekuatan produktif, yang telah dicapai pada level tertentu, datang seiring dengan konflik dalam hubungan produksi yang juga telah dikembangkan.

Mode produksi selalu berhubungan dengan kekuasaan produktif. Kekuasaan produktif dalam pemenuhan kebutuhan hidup terkait dengan kondisi - kondisi sosial, proses intelektual dan politik secara umum. Kesadaran manusia tidak menentukan keberadaannya sebagai makhluk hidup, justru sebaliknya bahwa keberadaannya sebagai mahkluk sosial itulah yang menentukan kesadaran seseorang. Dalam tahap perkembangan tertentu, material kekuasaan produktif masyarakat bertentangan dengan hubungan produksi dan bentuk perkembangannya justru malah menjadi belenggu tersendiri (Marx dan Engels, 2001).

Reportase Investigasi Trans TV sebagai salah satu jurnalisme investigasi yang seharusnya dapat menghadirkan informasi dengan lebih lengkap dan detail melalui investigasi lebih mendalam mengenai pembuatan terasi palsu justru menjadi tempat pertarungan kepentingan pemberitaan dan kepentingan bisnis. Sudah bisa ditebak kalau pada akhirnya kepentingan bisnislah yang menang, dan kepentingan pemberitaan cenderung mengalah secara paksa. Model jurnalisme investigasi dijadikan mesin untuk meraup keuntungan sebanyakbanyaknya walaupun harus berjalan diluar prinsip - prinsip jurnalisme yang sebenarnya demi kepentingan komersialisasi.

Komersialisasi media merupakan proses dinamis dan konstant mencakup 
keseluruhan operasional media massa untuk memenuhi permintaan pasar. Proses komersialisasi tersebut berpenetrasi ke seluruh aspek dalam media massa seperti periklanan, program, networking, modal, bahkan sampai dengan orientasi khalayak media. Hal tersebut sangat terkait dengan struktur organisasi media massa merupakan bentuk kompromi dari berbagai komponent dan struktur yang ada di dalamnya ${ }^{12}$.

Mekanisme pasar memegang peranan penting dalam proses komersialisasi, terutama adjustment terhadap suply dan permintaan pasar yang mempunyai dampak sangat besar dalam operasionalisasi media massa. Termasuk dalam hal isi atau kontent media massa, boleh dibilang bahwa supply pasar sangat tergantung pada content media agar dapat tetap berada dalam persaingan utama industri televisi. Apapun jenis media massanya, baik itu tradisional seperti koran, radio dan televisi maupun jenis media baru yaitu internet, kesemuanya itu mempraktekan konsep 'content is the core' sebagai operasional manajemen dan kegiatan persaingan pasar $^{13}$.

\section{PENUTUP}

Kebebasan pers dan liberalisasi sistem ekonomi global membawa industri televisi di Indonesia menjadi sebuah bagian dari kapitalisme tiada

12

http://www.csm.com.cn/en/business/pdf/010 /samples_en.pdf - tanggal akses 23 Mei 2010, $10.16 \mathrm{pm}$.

${ }^{13}$ Ibid http://csm.com akhir. Kepentingan untuk mengakumulasikan modal sebanyak banyaknya membuat sajian berita menjadi alat komersialisasi agar dapat mendatangkan pemasang iklan sebanyak mungkin.

Komersialisasi terjadi karena adanya permintaan pasar yang berimbas kepada struktur organisasi stasiun televisi tersebut. Oleh karenaya rating merupakan tolok ukur dimana suatu program disukai oleh masyrakat. Semakin tinggi rating maka dapat dipastikan semakin banyak pula iklan yang akan masuk dan itu berarti keuntungan, maka sebuah berita pun dalam penyajiannya akan dibuat sedemikian rupa, menarik terlihat penting walaupun informasi yang ditampilkan mungkin bukan informasi yang sebenarnya melainkan hanya berdasarkan rumor atau isu populer yang beredar dalam masyarakat.

Model investigasi jurnalisme hadir untuk menjawab kebutuhan tersebut. Namun oleh karena deadline, tuntutan dan faktor kebutuhan komersialisasi dari stasiun televisi itu sendiri maka jurnalis tidak memiliki otoritas dan idealisme dalam menyajikan sebuah berita. Kreatifitas hanya diperlukan untuk membuat bagaimana berita tersebut menarik dan menguntungkan. Sebagai alat produksi akan kekuasaan produksi, maka hHubungan produksi yang terjadi adalah hubungan materi obyektif yang ada pada masyarakat independen dari kesadaran manusia, dibentuk antara orang-orang dalam proses produksi sosial, pertukaran dan distribusi kesejahteraan materi. Tidak 
akan ada produksi tanpa hubungan produksi. Manusia tidak bisa memproduksi di luar struktur sosial mereka, baik itu dalam skala nasional maupun keluarga, hubungan produksi ada untuk semua produser.

Walaupun demikian, selaiknya jurnalis juga mempertimbangkan teknik - teknik dalam investigasi berita seperti verifikasi atau pengecekan ulang sehingga dapat menampilkan informasi yang akurat dan tidak serta merta memenuhi permintaan pasar.

\section{DAFTAR PUSTAKA}

Croteau, David \& Hoynes, William. The Bussiness of The Media, Corporate Media and the Public Interest. California: Pine Forge Press, 2001

Haryatmoko, DR. Etika Komunikasi: Manipulasi Media, Kekerasan, dan Pornografi. Yogyakarta: Kanisius, 2007

Marx, Karl and Frederick Engels. The German Ideology Part One, with Selections from Parts Two and Three, together with Marx's "Introduction to a Critique of Political Economy. New York: International Publishers, 2001.

Siregar, Ashadi dalam artikel Trend Jurnalisme Televisi

http://www.lintasberita.com/Entertainm ent/Sains/Proses_Produksi_Berita _TV - tanggal akses 9 Mei 2010, pukul $4.14 \mathrm{pm}$

http://www.transtvnews.co.id/index.php/

Sinopsis/reportase-

investigasi.html - tgl akses 9 Mei 2010, pukul 4.14 pm http://politikana.com/baca/2010/05/03/i nvestigasi-trans-tv-sebuahproduk-jurnalistik-atau-iklankomersial.html, akses 17 Mei 2010 pukul 8.41 pm

Siregar, Ashadi dalam artikel Etika Jurnalisme Televisi

www.marxist.org, tanggal akses 18 Mei 2010, $8.27 \mathrm{pm}$

Subiakto, Henry. Artikel Konsentrasi Media Massa dan Melemahnya Demokrasi - www.jurnal.unair.ac.id, tanggal akses 21 Mei 2010 jam 21.58 p 

